\title{
Evolution of ecosystem services in the Chinese Loess Plateau under climatic and land use changes
}

\author{
Changhong Su, Bojie Fu* \\ State Key Laboratory of Urban and Regional Ecology, Research Center for Eco-Environmental Sciences, Chinese Academy of Sciences, Beijing, China
}

\section{A R T I C L E I N F O}

\section{Article history:}

Received 14 November 2012

Accepted 28 December 2012

Available online 5 January 2013

\section{Keywords:}

Loess Plateau

Ecosystem service

Sediment control

Water yield

Net primary production

\begin{abstract}
A B S T R A C T
Due to the lengthy historic land use by humans and the climate change characterized by warming and drying, the Loess Plateau has been plagued by ecosystem degradation for a long time. A series of ecological conservation projects launched since the 1970s altered the land use pattern greatly, and exerted a profound influence on the ecosystem services. Based on the Integrated Valuation of Ecosystem Services and Tradeoffs (InVEST) and CarnegieAmes-Stanford Approach (CASA) models, we assessed the historical fluctuation of sediment control, water yield, and net primary production (NPP) in the Loess Plateau. The results showed that sediment retention was greatly consolidated indicated by the sharp decrease of sediment export. Water yield decreased at first and increased later. Both sediment export and water yield showed an increasing 'spatial homogenization' tendency during the period. NPP was steady between 1990 and 2000, and then increased greatly after 2000. Ecosystem services are interlinked closely and complexly. Correlation analyses indicated a positive relationship between the difference in sediment export and water yield $\left(r^{2}=0.776^{* *}\right)$ from 1975 to 2008, with negative correlations between the difference of NPP and water yield $\left(r^{2}=-0.422^{* *}\right) /$ sediment export $\left(r^{2}=-0.240^{*}\right)$ from 1990 to 2008. This, to some extent, implies that there are tradeoffs between the services of water yield and sediment control/NPP, and there is synergy between sediment control and NPP. Climatic and land use changes are the major drivers on ecosystem services fluctuation. Correlation analyses showed that the decrease of precipitation significantly hindered water yield $\left(r^{2}=0.980^{* *}\right)$ and sediment export $\left(r^{2}=0.791^{* *}\right)$. The increase of temperature exerted a slight negative influence on water yield $\left(r^{2}=-0.350^{* *}\right)$. A spatial concordance existing between the 'cropland to grass/woodland' area and the high sediment control $\left(r^{2}=0.313^{* *}\right) / \mathrm{NPP}\left(r^{2}=0.488^{* *}\right)$ area indicated that the land use change from cropland to woodland/grassland significantly consolidated sediment control and NPP production. The observed spatio-temporal variation of ecosystem services and their correlations provide an operable criterion for land use management policies.
\end{abstract}

(c) 2013 Elsevier B.V. All rights reserved.

\section{Introduction}

Ecosystem services refer to natural conditions and utilities provided by ecosystems and ecological processes that sustain human life (Daily, 1997). Ecosystem services haven't been given due attention in government policies and land management practices until 1970 when the very term of 'ecosystem service' was coined (SCEP, 1970). The inherent pro bono trait of most ecosystem service hinders its involvement in the policy making process (Jack et al., 2008). According to the Millennium Ecosystem Assessment, some 60\% of the ecosystem services studied have been degraded during the past 50 years (MA, 2005).

Various researchers conducted ecosystem services assessments in the Loess Plateau. Fu et al. (2011) assessed the soil erosion control in the Loess Plateau with the Universal Soil Loss Equation (USLE) model.

\footnotetext{
* Corresponding author at: State Key Laboratory of Urban and Regional Ecology. Research Center for Eco-Environmental Sciences, Chinese Academy of Sciences, P.O. Box 2871, Beijing 100085, China. Tel./fax: + 861062923557.

E-mail address: bfu@rcees.ac.cn (B. Fu).
}

Lü et al. (2012) assessed the ecological effects of Grain for green (GfG) project by evaluating the services of water regulation, soil conservation, carbon sequestration, and grain production. Researchers also analyzed ecosystem services at the watershed scale within the Loess Plateau (Chang et al., 2012; Su et al., 2012). Albeit abundant case studies, few have paid enough attention to long-term fluctuations of ecosystem services in the Loess Plateau, even though long term study is necessary in detecting the ecosystem services' response to climate change. More specifically, the intrinsic spatial and temporal scale dependence of ecosystem services per se requires long term studies. The scarceness in this regard is possibly due to the low availability and quality of complete data sets for past time, e.g., remote sensing data of the CORONA was available no earlier than 1958 , and is not compatible with current ecological models.

Models play significant roles in ecosystem services evaluation, especially at large scale. MA (2005) assessed a spate of ecosystem services by a series of models, e.g., assessing the coupling societybiosphere-climate system with the Integrated Model to Assess the Global Environment (IMAGE), predicting the supply, demand and 
prices of agricultural commodities with the International Model for Policy Analysis of Agricultural Commodities Trade (IMPACT), and projecting water budgets with the Water-Global Assessment and Prognosis (WaterGap) model (Tallis and Kareiva, 2006). Along with the rapid advancement of computer and Geographic Information System (GIS) technology, various spatial explicit models were developed, e.g., Century and Carnegie-Ames-Stanford Approach (CASA; Potter et al., 1993) for net primary production, Water Erosion Prediction Project (WEPP; Laflen et al., 1991, 1997) and Soil and Water Assessment Tool (SWAT; Arnold et al., 1998) for soil and water conservation. Moreover, various models were assembled to evaluate multiple ecosystem services simultaneously, such as the Global Unified Metamodel of the Biosphere (GUMBO; Boumans et al., 2002), Multi-scale Integrated Model of Ecosystem Services (MIME; Boumans and Costanza, 2007), and Integrated Valuation of Ecosystem Services and Tradeoffs (InVEST; Tallis et al., 2011), in which InVEST was widely used due to its openness and progressive improvement. Yet the model assemblages hasn't achieved the goal of quantifying the interrelations (tradeoff or synergy) among ecosystem services.

As an ecologically vulnerable area, the Loess Plateau is located in the upper and middle reaches of the Yellow River in northern China. For long history, the Loess Plateau has been plagued by meager and unevenly distributed precipitation, vegetation degradation, and soil erosion. To make things worse, long term entrenched destructive farming practices further exacerbated the soil erosion and water stress. The selection of types of ecosystem services should reflect the ecological constraints of the study area. Given the austere soil and water loss of the Loess Plateau, the potential vegetation degradation and subsequent climate warming, we selected sediment control, water yield, and net primary production as the three ecosystem services most apropos to the Loess Plateau.

In this paper we used the Loess Plateau as our study area, assessing the sediment control, water yield, and net primary production (NPP) of the years of $1975,1990,2000$, and 2008 . We selected these years due to the availability of satellite images. Our aims were to: (1) assess the fluctuation of the three ecosystem services during the past 30 years, (2) analyze the potential tradeoffs or synergy among the ecosystem services, and (3) discuss the effects of climate change and land use/land cover (LULC) change on ecosystem services.

\section{Study area}

The Loess Plateau $\left(33^{\circ} 43^{\prime} 7^{\prime \prime} \mathrm{N}-41^{\circ} 16^{\prime} 7^{\prime \prime}, 100^{\circ} 54^{\prime} 7^{\prime \prime}-114^{\circ} 33^{\prime} 7^{\prime \prime} \mathrm{E}\right)$ is located in the upper and middle reaches of the Yellow River in northern China (Fig. 1). With an area of over $640,000 \mathrm{~km}^{2}$, the Loess Plateau is the third largest plateau in China. The area straddles three climatic zones from south to north: semi-humid, semi-arid, and arid. The pivotal natural vegetation includes broadleaved deciduous forest, forest-steppe, steppe, and desert-steppe. The region belongs to a temperate continental climate with mean annual temperatures ranging from $4{ }^{\circ} \mathrm{C}$ to $14{ }^{\circ} \mathrm{C}$ and annual precipitation ranging from 200 to $750 \mathrm{~mm}$. Around $60-70 \%$ of the rainfall occurs in highly erosive heavy storm-lit that fall from June to September.

In the quaternary and particularly the Holocene periods, the Loess Plateau was dominated by grassland and forest steppe (Shang and $\mathrm{Li}$, 2010). The last 2000 years saw a significant degradation of vegetation due to ever-increasing human activities (Wang et al., 2006). Intensive land use (mainly slope farming) and exploitative management accelerated soil erosion, resulting in the loss of grassland and natural forest. As an area that accounts for $6.6 \%$ of China territory, the Loess Plateau feeds $8.5 \%$ of the Chinese population with a population density of 168 persons $/ \mathrm{km}^{2}$. Population growth and its related factors, i.e., urbanization, agricultural expansion, and natural resources exploitation caused daunting challenges for ecosystem rehabilitation in the Loess Plateau. The average erosion modulus was calculated to be $5000-10,000$ ton $/ \mathrm{km}^{2}$, with the highest up to 20,000-30,000 ton $/ \mathrm{km}^{2}$ (Cai, 2001), which constitutes the major source of sediments in the Yellow River (Fu et al., 2011). To make matters worse, undue water utilization further devastated the situation. For a region accounting for only $2 \%$ of the total water resources in China, the water utilization ratio of the major rivers in the Loess Plateau was up to $70 \%$, far exceeding the internationally recognized water utilization threshold of 40\% (Gao et al., 2009).

\section{Methods}

\subsection{Ecosystem services quantification}

In this study, sediment control and water yield were assessed by InVEST, a model assemblage jointly developed by Stanford University, the World Wildlife Fund (WWC), and The Nature Conservancy (TNC), under the auspices of the Natural Capital Project (http://www. naturalcapitalproject.org/InVEST.html). InVEST is useful in informing the decision-making process by quantifying and mapping the distribution of ecosystem services under alternative scenarios (Tallis et al., 2011). As an ongoing improvement process, the InVEST model is a work in progress, for which we used the version of InVEST 2.2.2. For NPP, we used the process-based CASA model with which we had some experience (Potter et al., 1993).

\subsubsection{Sediment control}

InVEST calculates a land parcel's sediment transportation by Universal Soil Loss Equation (USLE). The results can be illustrated at pixel scale and sub-watershed scale, but the latter is more suitable to interpretation. The data input includes geomorphology, climate, vegetation, and management practices. Vegetation not only keeps sediment from eroding where it grows, it also traps sediment that has eroded upstream. The ordinary USLE equation overlooks this component of sediment dynamics. InVEST accounts for it with an iterative analysis that estimates the sediments eroded on all pixels trapped by downstream vegetation based on the ability of vegetation of each pixel in capturing and retaining sediment. The model determines the total sediment load exported that reaches the stream from each pixel on the landscape. For some key parameters, we were not merely relying on InVEST. For example, we calculated the soil erosive factor $\mathrm{K}$ by the Erosion/Productivity Impact Calculator (EPIC) model based on soil texture (Williams and Arnold, 1997). As the principle states that the rainfall erosive factor $R$ equals $E$ (the kinetic energy of rainfall) times I30 (maximum intensity of rain in $30 \mathrm{~min}$ in $\mathrm{cm} / \mathrm{h}$ ) which requires special data not available to us, we tailor-made the methods for calculating the R factor in the Chinese context by applying a method of half-month precipitation erosive forces (Zhang and Fu, 2002), a modular imbedded in the Chinese Soil Loss Equation (CSLE; Liu et al., 2002).

\subsubsection{Water yield}

In InVEST model, the water yield is calculated based on the Budyko curve and annual average precipitation with the equation as follows (Budyko, 1974):

$Y x j=\left(1-\frac{A E T x j}{P x}\right) \cdot P x$

where $A E T_{x j}$ is the annual actual evapotranspiration on pixel $x$ with land use/cover category $j, P_{x}$ is the annual precipitation on pixel $_{x}$. In the equation, the evapotranspiration partition of the water balance, $\frac{A E T x j}{P x}$, is an approximation of the Budyko curve developed by Zhang et al. (2001):

$$
\frac{A E T x j}{P x}=\frac{1+\omega x+R x j}{1+\omega x R x j+\frac{1}{R x j}}
$$

where $R_{x j}$ is the dimensionless Budyko dryness, defined as the ratio of potential evapotranspiration to precipitation, and $\omega_{x}$ is a dimensionless 

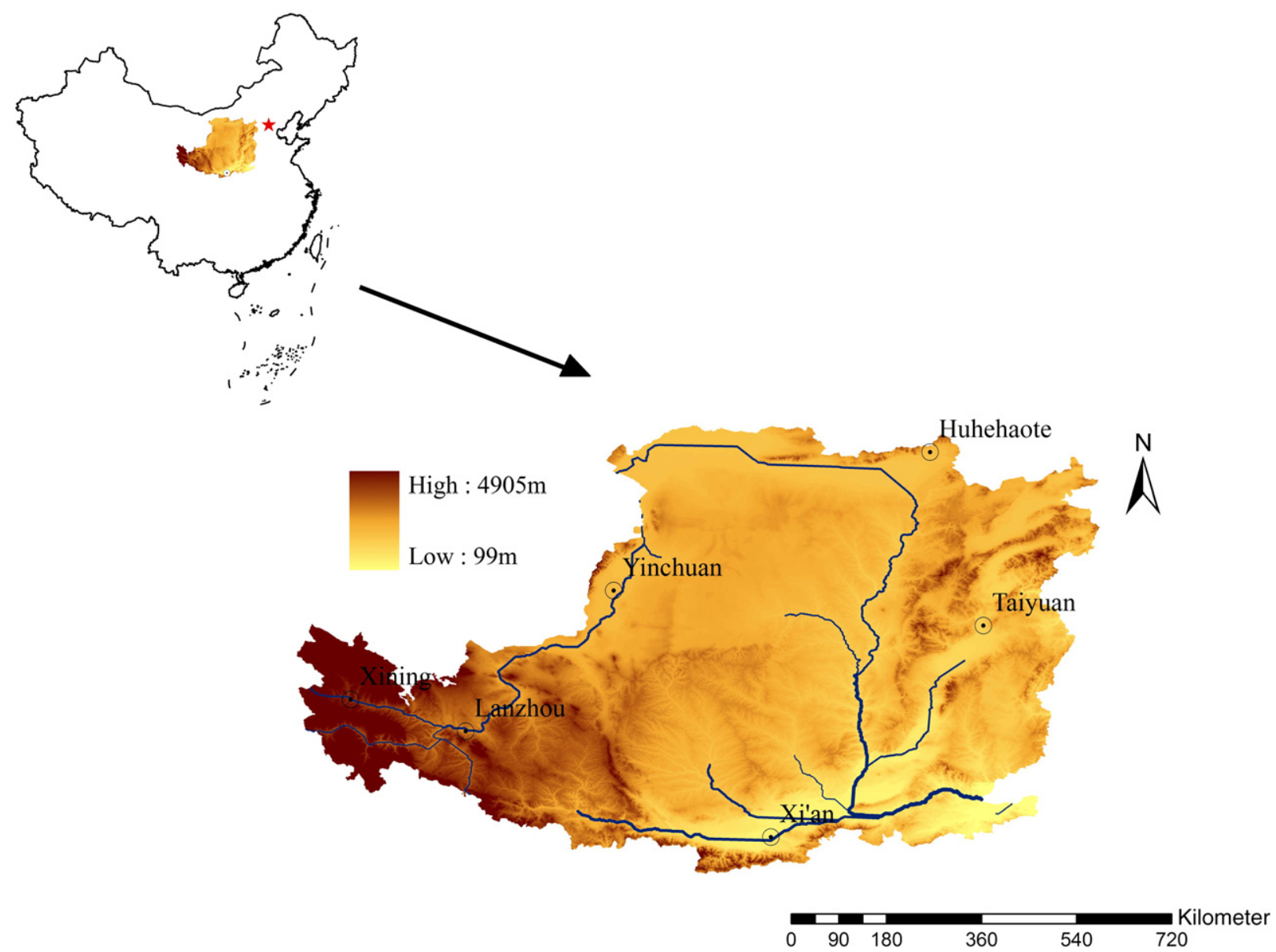

Fig. 1. Location of the study area.

ratio of plant accessible water storage to expected precipitation during the year (Budyko, 1974).

The input data includes average annual precipitation, annual potential evapotranspiration (ET0), soil depth, plant available water content (PAWC), Land Use and Land Cover (LULC), root depth, elevation, etc. We calculated the PAWC, i.e., the fraction of water that can be stored in the soil profile available for plants' use, based on the soil texture according to Saxton et al. (1986). ET0 was calculated based on the Penman-Monteith equation. Similar to sediment control, results of water yield can also be illustrated at either pixel scale or sub-watershed scale, with the latter more interpretable in mechanism.

\subsubsection{NPP}

We calculated the NPP based on the process-based CASA model. This model advocates that plant productivity is correlated with the amount of photosynthetically active radiation absorbed or intercepted by green foliage (Monteith and Moss, 1977; Potter et al., 1993). Three basic equations are involved:

$N P P=\sum[\operatorname{APAR}(t) \times \varepsilon(t)]$

$\operatorname{APAR}(x, t)=\operatorname{PAR}(x, t) \times \operatorname{FPAR}(x, t)$

$\varepsilon=\varepsilon^{*} \times T_{1} \times T_{2} \times W$

where $P A R$ is the total incident photosynthetically active radiation $(0.4-0.7 \mu \mathrm{m})\left(\mathrm{MJ} / \mathrm{m}^{2}\right)$; FPAR is the fraction of PAR absorbed by the vegetation canopy, which is decided by vegetation type and coverage; $A P A R$ is canopy-absorbed incident solar radiation integrated over a time period; $\varepsilon$ and $\varepsilon^{*}$ refer to actual light use efficiency $(\mathrm{g} / \mathrm{mJ})$ and maximum light use efficiency respectively; $T_{1}$ and $T_{2}$ refer to temperature stress coefficients and $W$ refers to the water stress coefficient. As CASA requires a relatively complete set of satellite images (at least one image per month annually), which is not available for the year 1975, we skipped the calculation of NPP in 1975.

\subsection{Correlation analysis}

Sediment export and water yield are presented at sub-watershed scale, whereas NPP are presented at pixel scale. To overcome the scale mismatch, we allocated the value of NPP to each sub-watershed by the 'zonal statistic' modular of the ArcGis software. The correlations among sediment export, water yield, and NPP were analyzed at the sub-watershed scale.

\subsection{Data preparation}

LULC were extracted from satellite images, i.e., Landsat MSS (60 m) of 1975, Landsat TM ( $30 \mathrm{~m}$ ) of 1990, Landsat ETM (30 m) of 2000, and Cbers (19.5 m) of 2008. Due to low availability, it is difficult to obtain complete sets of satellite images of the same date for an area as big as $640,000 \mathrm{~km}^{2}$. We supplemented them with images of adjacent years. The Cbers images of 2008 were resampled to $30 \mathrm{~m}$ resolution to make them compatible to the images of the other years. All the images were selected during the plant-growing seasons, i.e., from June to October. For CASA model, a 10-day composite NOAA Pathfinder AVHRR Land (PAL) dataset $(8 \mathrm{~km})$ of 1990 and MODIS images $(1 \mathrm{~km})$ of 2000 and 2008 were used to calculate NPP for 1990, 2000, and 2008. Raster formatted soil data, i.e., soil texture, soil depth, and soil type, were obtained from the Institute of Soil Science of the Chinese Academy of 
Sciences. We used these soil data for calculation of soil erodability for sediment control. Climatic data were obtained from the China Metrological Administration including daily maximum and minimum air temperature, mean wind speed, hours of sunshine, air pressure, and relative humidity. These climatic data were used to calculate the ETO for the water yield and erosivity for sediment control. DEM of $90 \mathrm{~m}$ resolution was used to analyze the factors of slope length/angle for sediment control. InVEST requires delineation of watershed and sub-watershed, for which we delineated the whole study area into 6 watersheds and 96 sub-watersheds based on the $90 \mathrm{~m}$ resolution DEM through the ArcSWAT software.

\section{Results}

\subsection{Sediment control}

In this study, sediment control was embodied by the curbing of sediment exports, which had a roughly similar spatial pattern of low in the northwest and high in the southeast across the four years (Fig. 2).
Sediment control was consolidated demonstrated by the general decrease in average sediment exports from 7.31 ton/ha in 1975 to 4.16 ton/ha in 2008 (except for a relatively constant sediment export of 7.40 ton/ha from 1975 to 1990) with a variation margin ranging from -22.1 ton/ha to 2.27 ton/ha (Fig. 2). The decreasing area of sediment export was located primarily in the south, and accounted for $63.2 \%$ of the total area. Some areas (accounting for $36.8 \%$ of the total area) in the northwest and northeast underwent increased sediment exports with a small margin of 0 to -2.27 ton/ha. As time went on, the sediment export demonstrated a 'spatial homogenization' tendency that tended to narrow the disparities across the whole area.

\subsection{Water yield}

Similar to sediment export, water yield in the Loess Plateau also showed a spatial pattern of low in the northwest and high in the southeast for the four years (Fig. 3). The average water yield decreased slightly from 869.41 ton/ha in 1975 to 846.0 ton/ha in 1990, plummeted to 546.0 ton/ha in 2000 and rebounded slightly

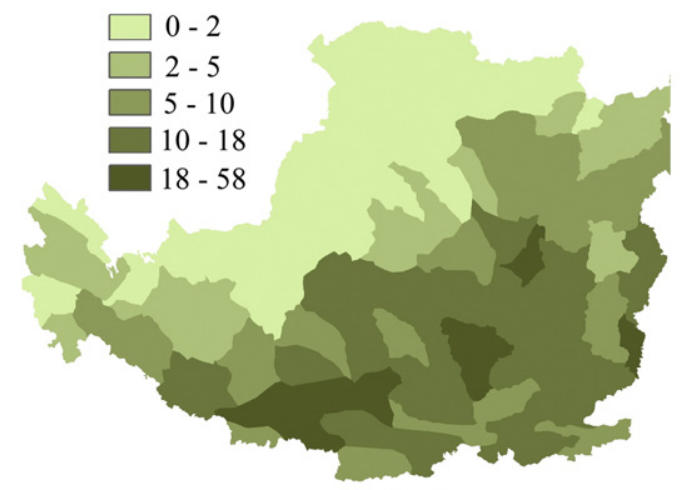

1975

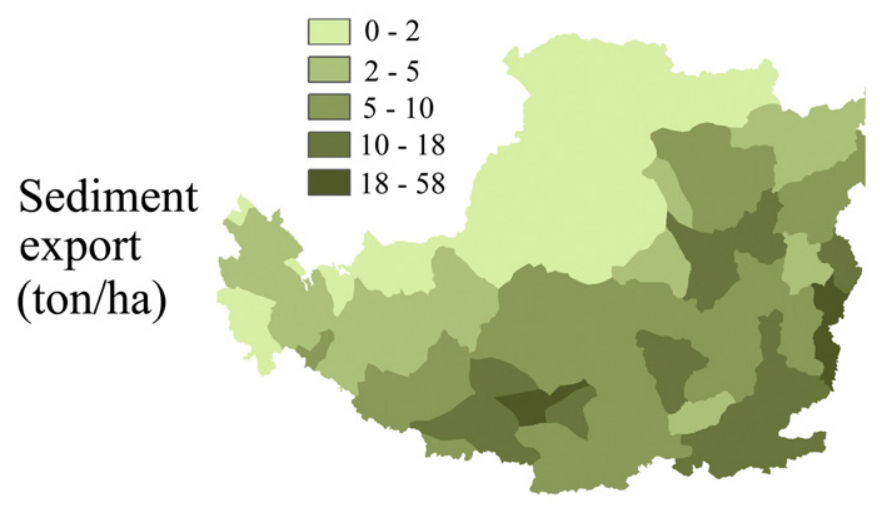

2000

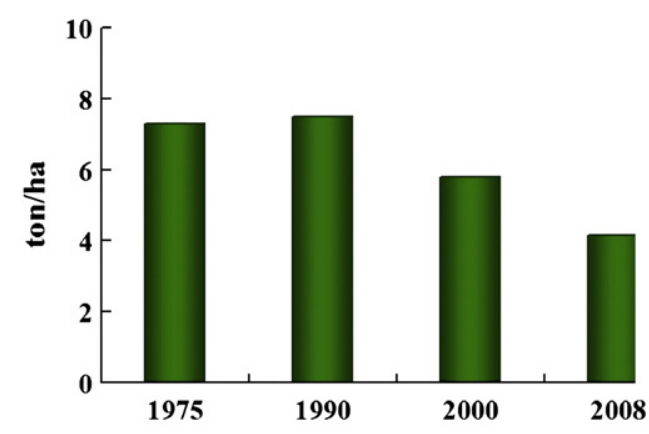

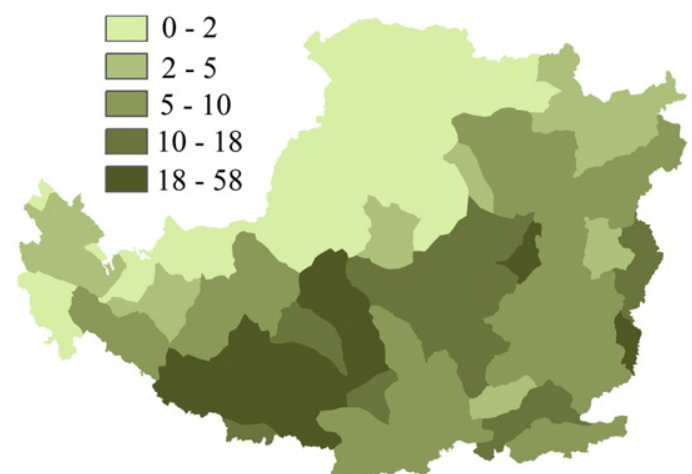

1990

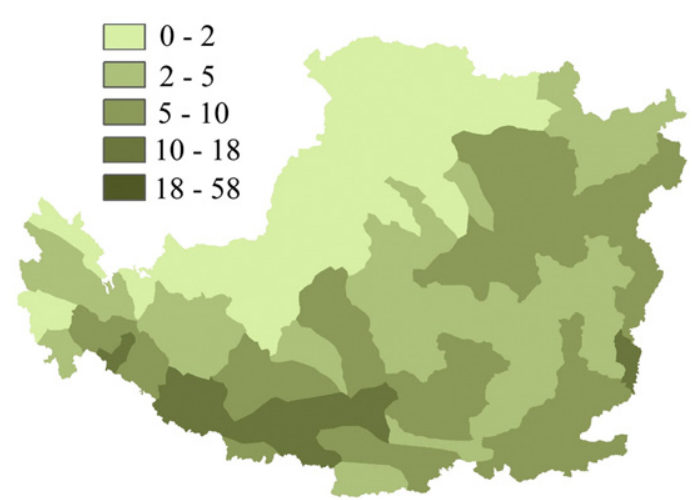

2008

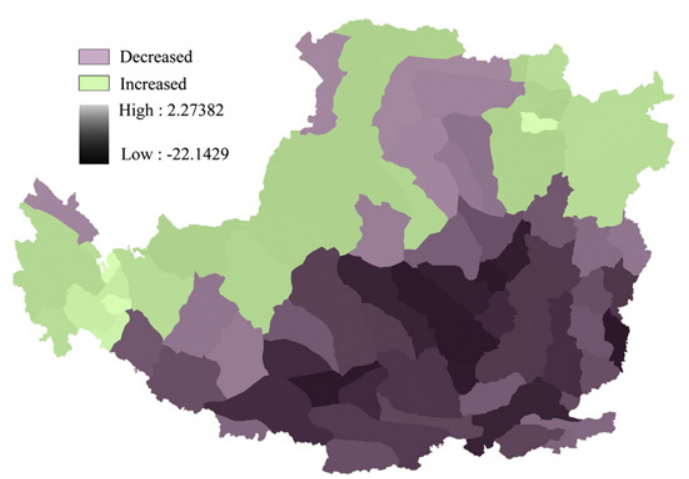

Fig. 2. Sediment export of the Loess Plateau at sub-water scale. 
to 609.2 ton/ha in 2008. The fluctuation margin of water yield from 1975 to 2008 ranged between -1274.5 ton/ha and 405.5 ton/ha. The areas that underwent an increase in water yield were mostly in the north, accounting for $41 \%$ of the total plateau, whereas the remaining area (59\%) in the south showed a decrease in water yield. Similar to sediment export, the total area showed a 'spatial homogenization' tendency when time elapsed that tended to narrow the difference in water yield across the whole area.

\subsection{NPP}

NPP from 1990, 2000, and 2008 showed a similar spatial pattern, i.e., low in the northwest and high in the southeast (Fig. 4). Compared with 1990 and 2000, the year 2008 showed more intermediate-valued NPP along the northeast-southwest belt. Temporally, mean NPP of the Loess Plateau remained nearly constant from 1990 to 2000 at
7.00 ton/ha/a and then jumped to 8.72 ton/ha/a in 2008. From 1990 to $2008,76.7 \%$ of the Loess Plateau underwent an increase in NPP, whereas the remaining $23.3 \%$ sporadically scattered area showed a decrease in NPP. Albeit trivial in proportion, the NPP decrease area had a large margin of -19.57 ton/ha, wider than the 13.87 ton/ha for the NPP increase area.

\subsection{Correlations between ecosystem services}

Through analyzing the spatial correlations of sediment exports, water yield, and NPP, either the status quo or the differences of sediment export and water yield were positively linked $\left(r^{2}=0.776^{* *}\right.$ from 1975 to 2008; Table 1). NPP was positively correlated with sediment export/water yield for each individual year, yet the difference in NPP between 1990 and 2008 was negatively correlated with the other two $\left(r^{2}=-0.422^{* *}\right.$ and $r^{2}=-0.240^{* *}$ respectively; Table 1$)$.

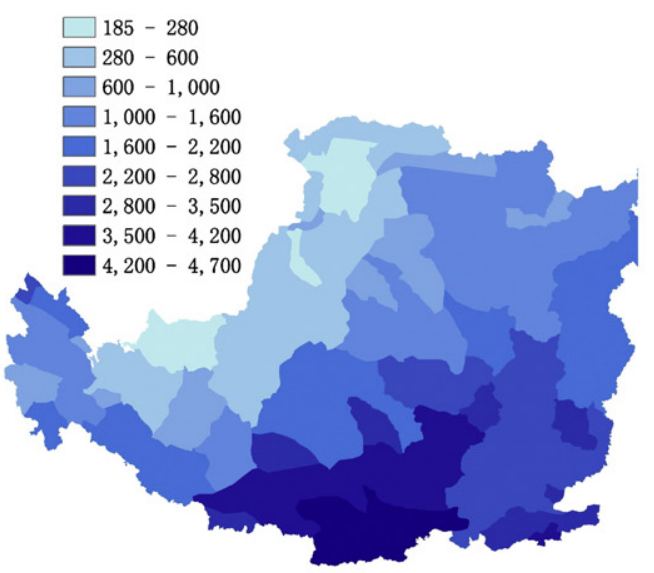

1975

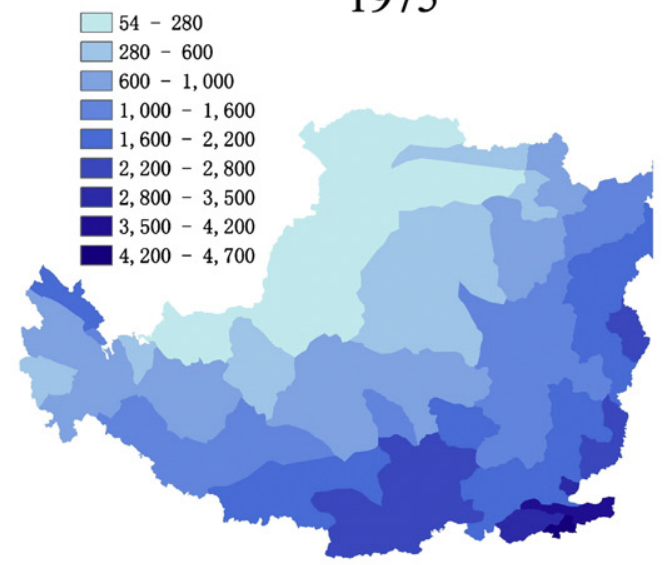

2000

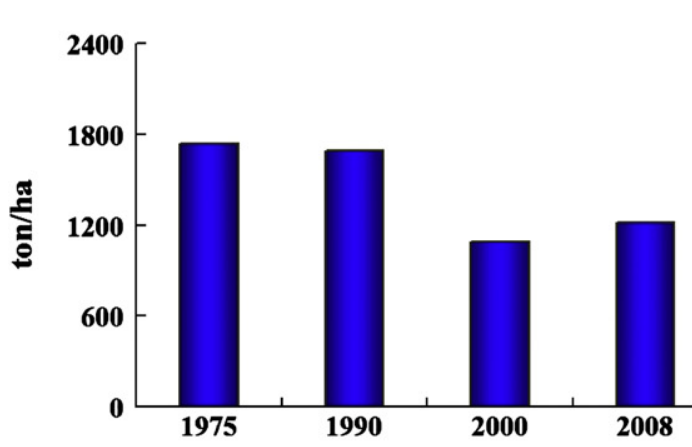

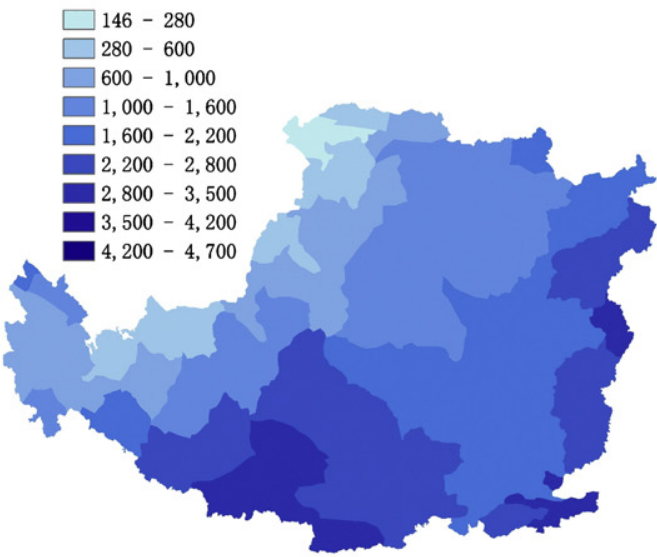

1990

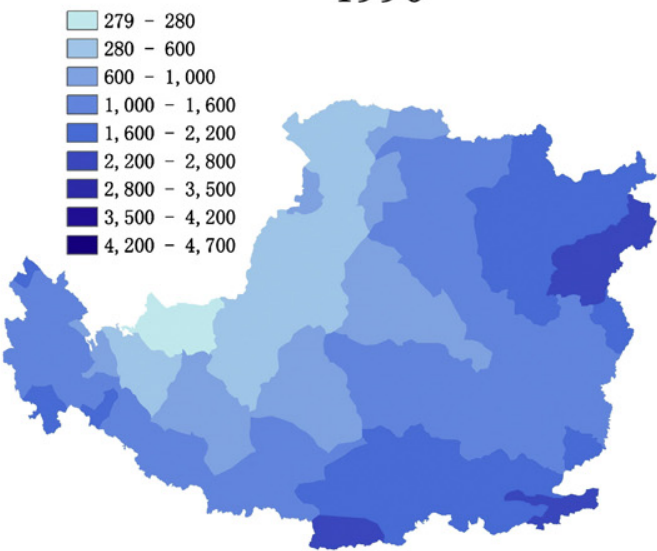

2008

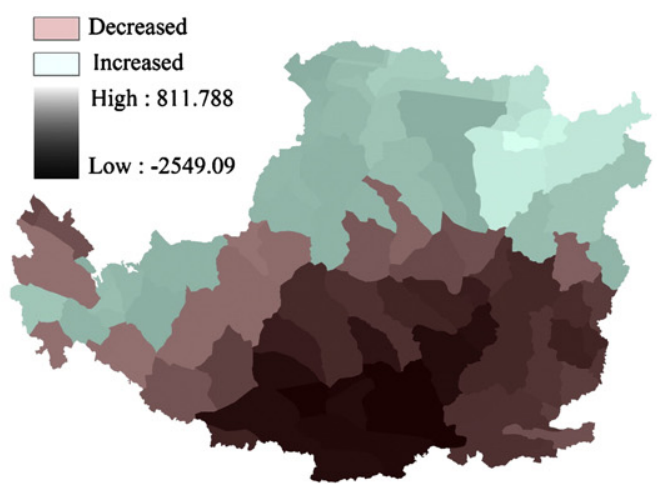

Fig. 3. Water yield of the Loess Plateau at sub-water scale. 
This, to some extent, indicates tradeoffs existing between water yield and sediment control/NPP, and synergy between sediment control and NPP.

\section{Discussion}

\subsection{Factors underlying ecosystem services fluctuation}

It is widely acknowledged that multiple factors drive the generation, states, and evolution of ecosystem services, such as LULC change, atmospheric carbon dioxide, biotic changes, warming, nitrogen deposition,

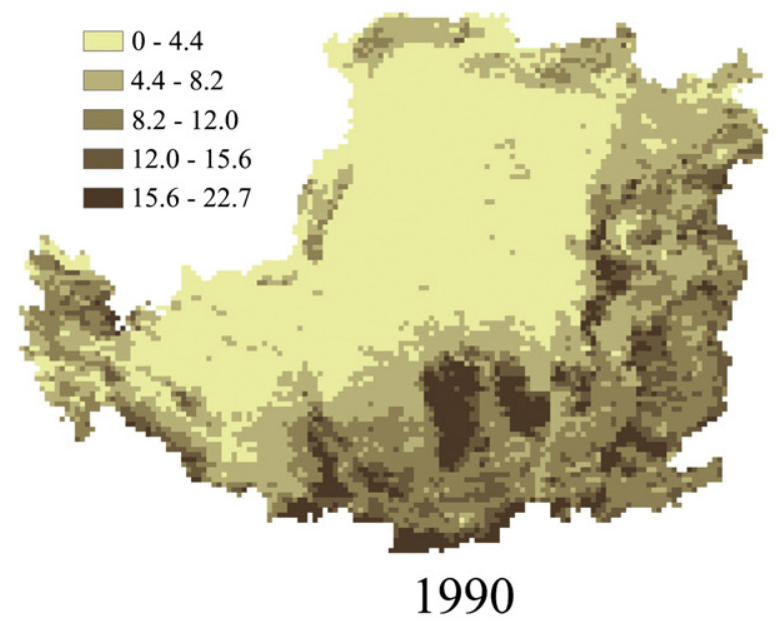

\section{Net primary production (ton/ha)}

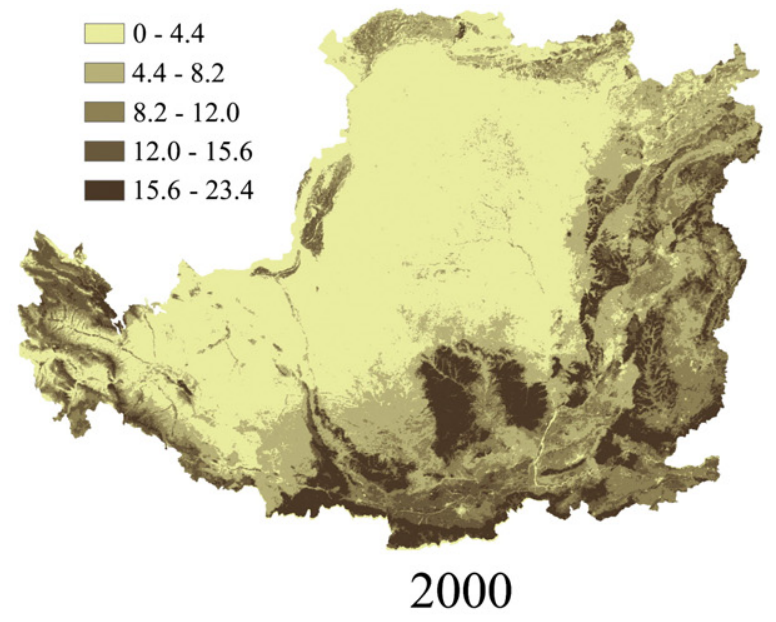
Norby, 2002). MA (2005) broadly divided these factors into direct (mostly physical) factors and indirect (mostly human) factors. At large spatio-temporal scale, climate change and land use are the major physical and human factors driving ecosystem services' fluctuation.

\subsubsection{Precipitation and temperature}

Precipitation and temperature play significant roles in shaping the process of sediment export, hydrological processes, and NPP. The past 30 years saw a warming and drying tendency in climate for the Loess

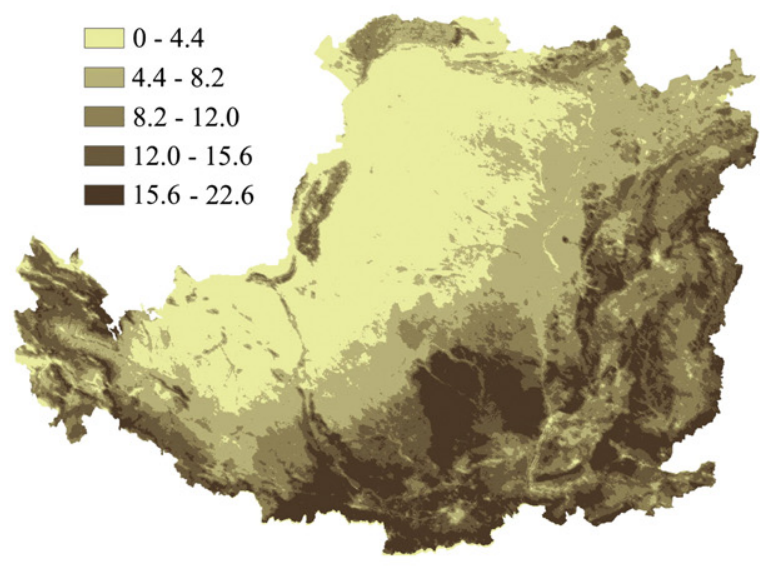

\section{8}
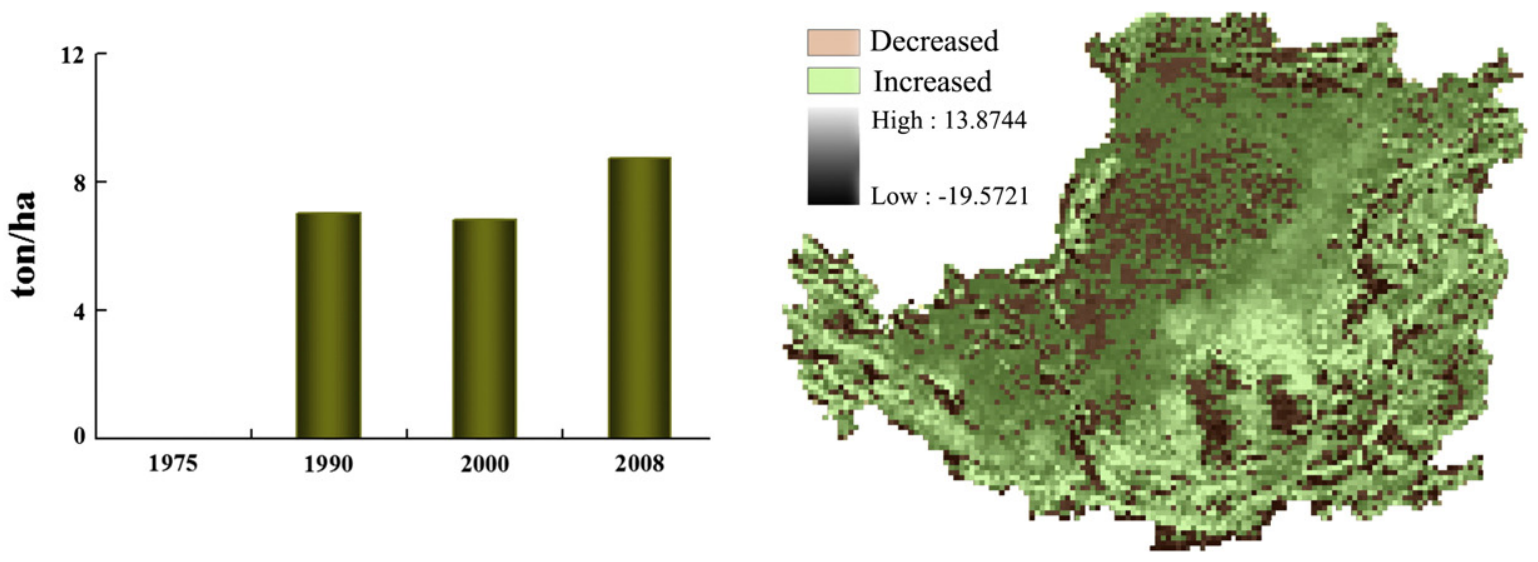

Fig. 4. Net primary production of the Loess Plateau at pixel scale. 
Table 1

Correlations among multiple ecosystem services.

\begin{tabular}{|c|c|c|c|c|c|c|}
\hline & & \multicolumn{5}{|c|}{ Water yield } \\
\hline & & 1975 & 1990 & 2000 & 2008 & 2008-1975 \\
\hline \multirow[t]{7}{*}{ Sediment export } & 1975 & $0.735^{* *}$ & - & - & - & - \\
\hline & 1990 & - & $0.726^{* *}$ & - & - & - \\
\hline & 2000 & - & - & $0.659^{* *}$ & - & - \\
\hline & 2008 & - & - & - & $0.530^{* *}$ & - \\
\hline & 2008-1975 & - & - & - & - & $0.776^{* *}$ \\
\hline & & \multicolumn{5}{|c|}{ Carbon sequestration } \\
\hline & & - & 1990 & 2000 & 2008 & 2008-1990 \\
\hline \multirow[t]{7}{*}{ Sediment export } & 1975 & - & - & - & - & - \\
\hline & 1990 & - & $0.525^{* *}$ & - & - & - \\
\hline & 2000 & - & - & $0.552^{* *}$ & - & - \\
\hline & 2008 & - & - & - & $0.646^{* *}$ & - \\
\hline & 2008-1990 & - & - & - & - & $-0.422^{* *}$ \\
\hline & & \multicolumn{5}{|c|}{ Carbon sequestration } \\
\hline & & - & 1990 & 2000 & 2008 & 2008-1990 \\
\hline \multirow[t]{5}{*}{ Water yield } & 1975 & - & - & - & - & - \\
\hline & 1990 & - & $0.742^{* *}$ & - & - & - \\
\hline & 2000 & - & - & $0.811^{\text {** }}$ & - & - \\
\hline & 2008 & - & - & - & $0.668^{* *}$ & - \\
\hline & 2008-1990 & - & - & - & - & $-0.240^{*}$ \\
\hline
\end{tabular}

** Correlation is significant at the 0.01 level (2-tailed).
$*$ Correlation is significant at the 0.05 level (2-tailed).

Plateau (Fig. 5). The linear rates of the temperature increase and precipitation decrease are $0.0514{ }^{\circ} \mathrm{C} / \mathrm{a}$ and $-1.287 \mathrm{~mm} / \mathrm{a}$, respectively. Correlation analyses showed that the decrease in precipitation significantly hindered the water yielding function $\left(r^{2}=0.980^{* *}\right)$ and sediment export $\left(r^{2}=0.791^{* *}\right)$. This is consistent with similar researches by McFarlane et al. (2012) and Fang et al. (2011). The increase of temperature showed a slightly positive relationship with NPP $\left(r^{2}=0.253^{*}\right)$, which was consistent with Peng et al. (2009) who argued that elevated temperature increases NPP through metabolically enhanced photosynthesis as well as carbon sequestration by increasing nutrient availability through higher rates of decomposition. Tang et al. (2012) used a hydrological model of Variable Infiltration Capacity (VIC) to simulate streamflow with temperature increase, and the results showed that the annual mean streamflow decreased when temperatures increased. Our research echoed Tang et al.'s (2012) results by a negative correlation between temperature increase and water yield $\left(r^{2}=-0.350^{* *}\right)$.

\subsubsection{Land use and land cover change}

Land use change represents the most substantial human alteration of the Earth's systems for long-term study (Vitousek et al., 1997). 1978 saw the start of the Three-North Shelter Forest Program (TNSFP), the then largest ecological reforestation program in the world accounting for $42.4 \%$ of Chinese territory. In 1995, various comprehensive ecological rehabilitation projects were carried out on small watersheds in the Loess Plateau. In 1999, the Chinese government launched the GfG project with the Loess Plateau as the pilot area. The major measures of these projects ranged from optimizing land use configuration, transforming slopes into terraces, restoring slope cropland into forest and grassland, enclosing the hillside and banning grazing, building reservoirs, and constructing basic farmland. Through these projects, land use and land cover changed greatly. From 1975 to 2008, woodland and grassland increased by $4695 \mathrm{~km}^{2}$ and $19,027 \mathrm{~km}^{2}$, respectively. At the same time, farmland decreased by $25,221 \mathrm{~km}^{2}$ (Fig. 6). Large areas of steep slope farmland were converted into grassland and woodland, especially during the 2000-2008 periods, thanks to the GfG project (Fig. 7). The vegetation recovery and conversions from farmland to grassland/woodland in particular, strongly enhanced ecosystem services in the Loess Plateau (Zheng, 2006; Feng et al., 2010; Deng et al., 2012). Our study echoed this by an observed spatial concordance between the 'cropland to grass/woodland' area and the sediment control $\left(r^{2}=0.313^{* *}\right) / \mathrm{NPP}\left(r^{2}=0.488^{* *}\right)$.

\subsection{Correlative mechanisms between ecosystem services}

Ecosystem services are closely linked characterized by non-linear relationships (Farber et al., 2002; van Jaarsveld et al., 2005). These relationships between ecosystem services boil down to trade-off and synergy across spatio-temporal scales. Bennett et al. (2009) argued that ecosystem services are interrelated due to (1) effects of common drivers, or (2) interactions among ecosystem services per se. In our research, sediment control and water yield are strongly correlated possibly because they share the common hydrological processes and the common drivers of precipitation and land use/land coverage change. As is self evident that the more sediment retained, the less freely water flows, and the more water penetration and lower water yield.

Researchers had explored deforestation's adverse environmental impacts and economic effects (Farley et al., 2005; Chisholm, 2010). Jackson et al. (2005) argued that the carbon sequestration-oriented plantation can help control groundwater recharge and upwelling, but reduce stream flow and salinates or acidifies some soils. Scenario simulation suggests that climate feedbacks of the photosynthesis process-driven carbon sequestration are unlikely to offset such water losses and could even exacerbate them (Jackson et al., 2005).

Zhang et al. (2008) argue that vegetation recovery in the Loess Plateau effectively decreased stream flow. Our research showed positive relationships between the status quo of NPP and sediment export/ water yield for which we considered it as pseudo-positive (Table 1). The reason may be attributed to the strongly gradient pattern of precipitation increasing from around $200 \mathrm{~mm}$ in the northwest to around $750 \mathrm{~mm}$ in the southeast. Subtracting the raster image of ecosystem services from 2008 to 1990 can effectively filter the impact of background climatic differences. The negative correlations between the difference of NPP and sediment export/water yield from 1990 to 2008 indicate that tradeoffs exist between NPP and water yield, and a synergy between NPP and sediment control.

\subsection{Uncertainties of model-based ecosystem services assessment}

Some uncertainties exist in our assessment of ecosystem services. For sediment control, the USLE model adopted by InVEST was mainly used for sheet wash erosion (erosion from gentle slopes)(FAO, 2002). This did not address the rill-inter-rill, gullies, or stream-bank erosion. In addition, the relationship between rainfall intensity and kinetic energy may not hold for mountainous areas because it has only been tested in the America Great Plains. Up until now, InVEST was used mostly for identifying the hot spot area and comparing multiple ecosystem services by relative values, rather than extracting the absolute value for each ecosystem service. In this article, we did not use the sediment retention value given directly by InVEST for its one-order-of-magnitude difference with our previous similar works in the Loess Plateau (Fu et al., 2011; Lü et al., 2012; Su et al., 2012). The reason accounting for this huge disparity may be attributed to the iteration processes InVEST applied in calculating the trapping of additional sediments upstream for which InVEST blamed the ordinary USLE neglected.

Uncertainties also exist for water yield. The principle assumes that all water produced in a watershed in excess of evapotranspiration arrives at the watershed outlet. It fails to consider water capture by means other than primary human consumptive uses. Surface water-ground water interactions are neglected entirely. The process-based CASA model we used for NPP does not exempt itself from uncertainties, as we used two types of remote sensing data with different resolutions (NOAA PAL of $8 \mathrm{~km}$ resolution for 1990, and MODIS of $1 \mathrm{~km}$ resolution for 2000 and 2008).

The LULC categorization scheme is also a possible source of uncertainty. The larger the study area, the broader categories we can manage in interpreting the remote sensing image, which will cause the loss of some critical information. For example, if all forest is regarded as one LULC class, the difference in soil retention, water penetration and 

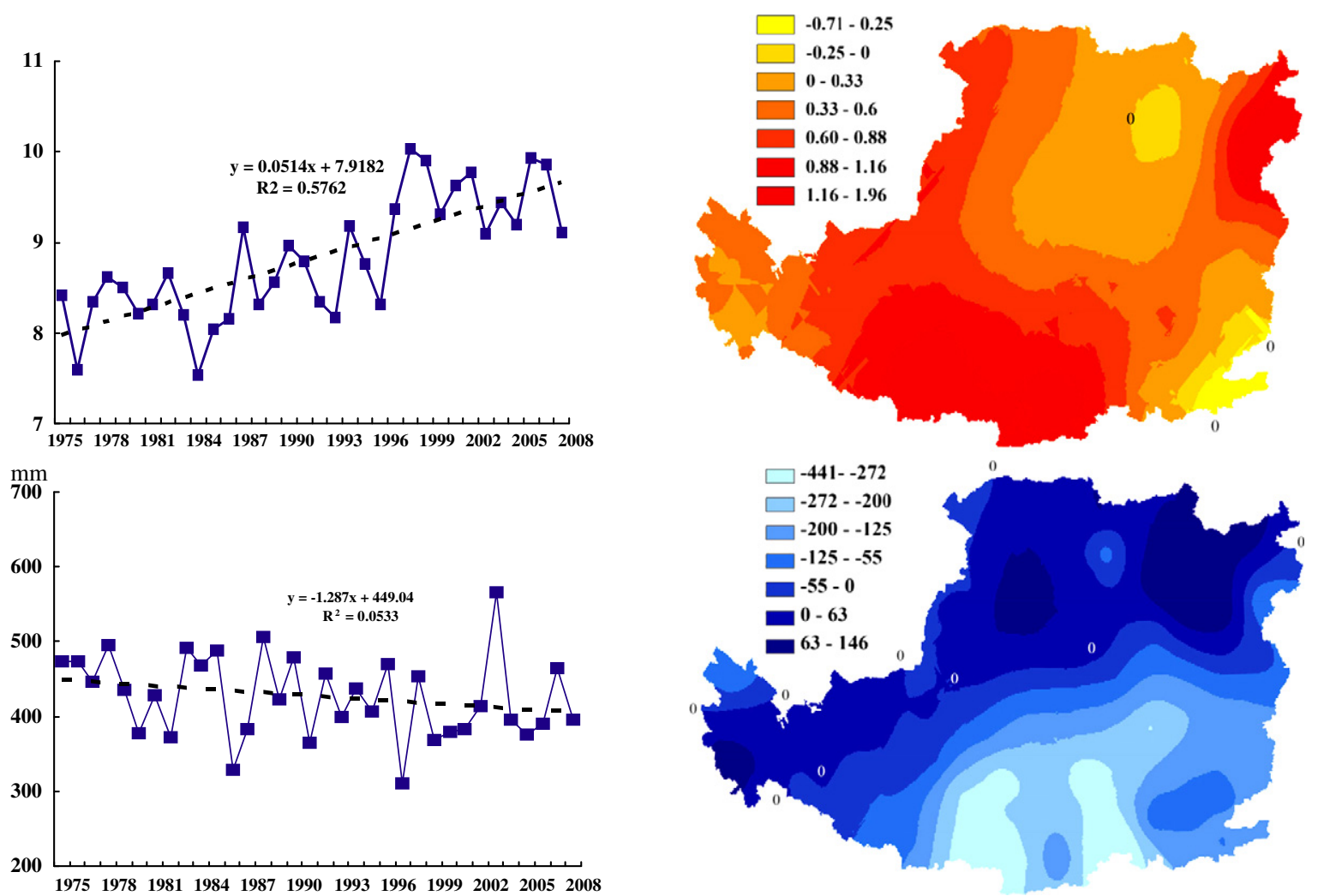

Fig. 5. Variations of temperature and precipitation in the Loess Plateau over the past 30 years.
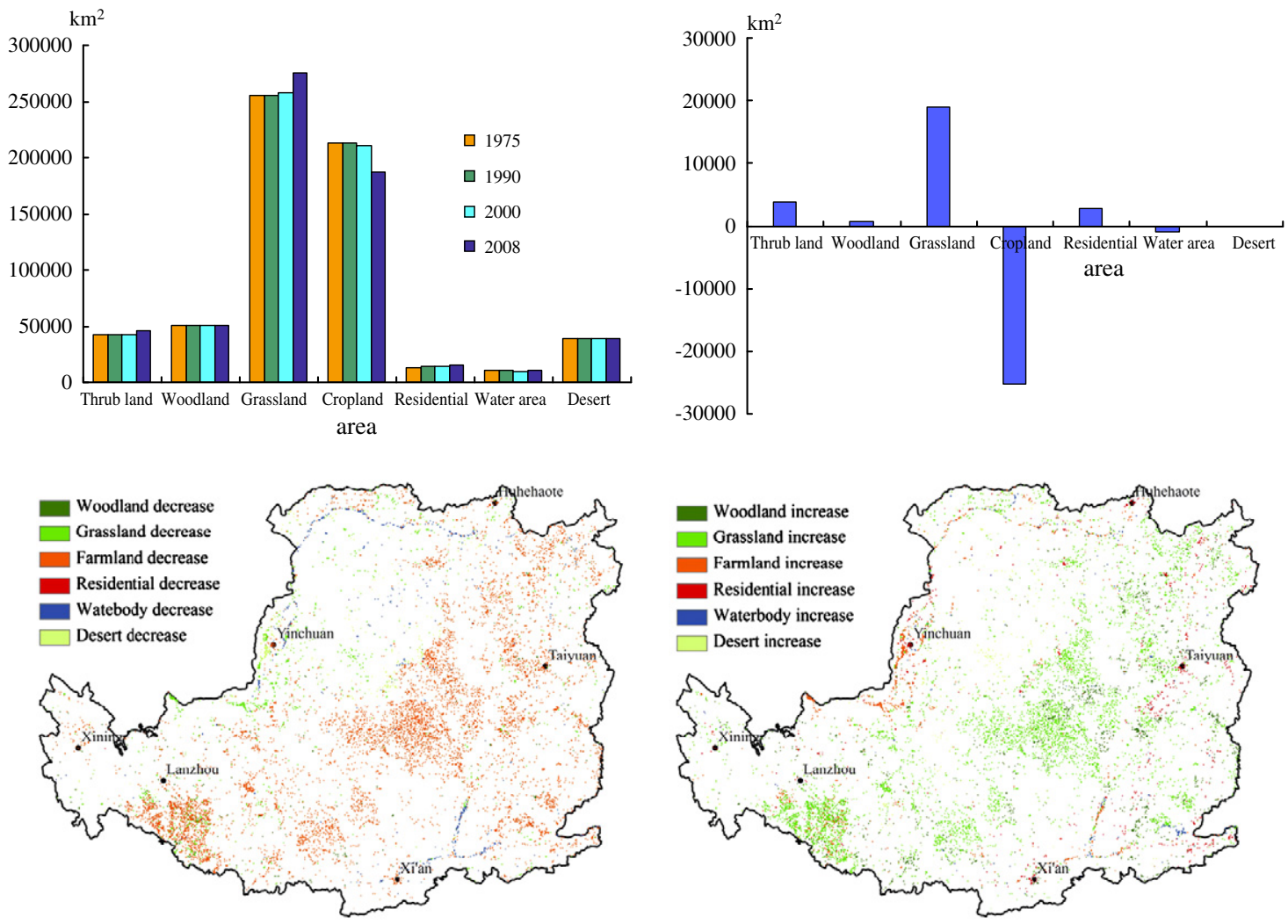

Fig. 6. Land use change in the Loess Plateau over the past 30 years. 

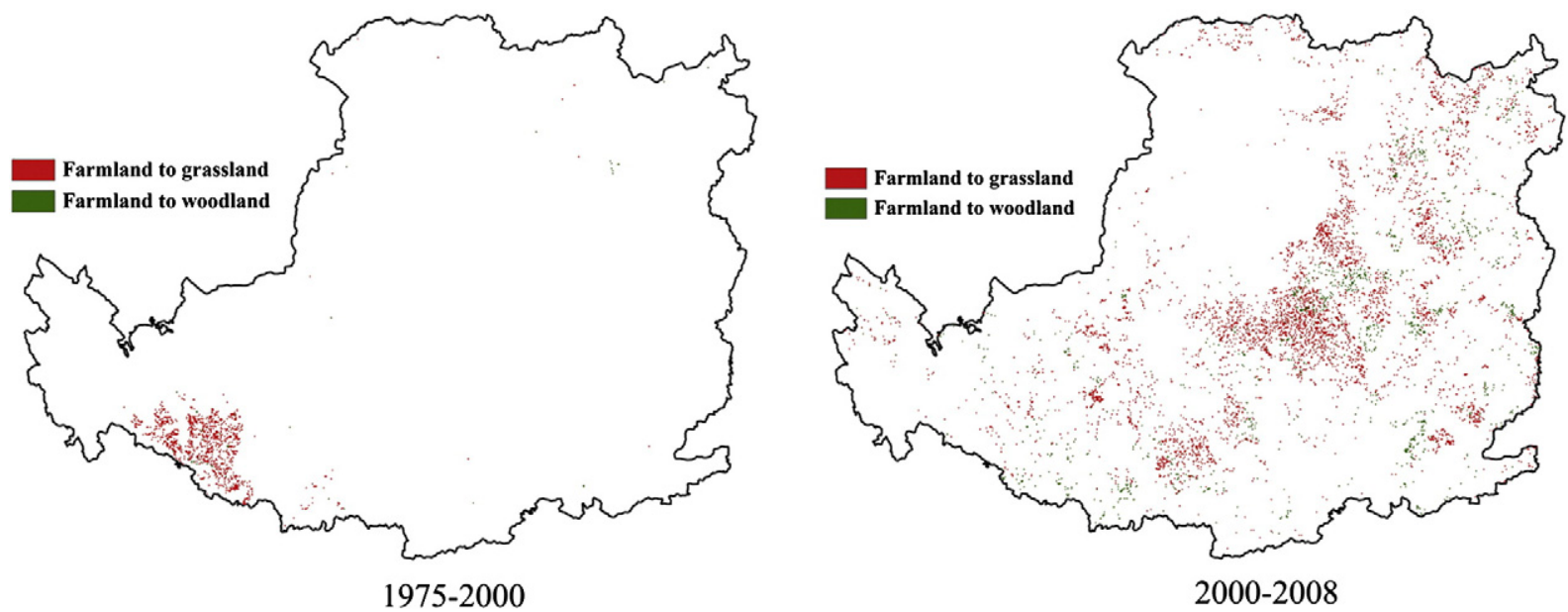

Fig. 7. Areas undergoing conversion from cropland to grassland/woodland in the Loess Plateau.

evapotranspiration, or NPP producing ability between an old growth forest and a newly-planted forest will be neglected.

\section{Conclusions}

Based on the InVEST and CASA models, we assessed the historical fluctuation of sediment control, water yield, and NPP in the Loess Plateau. The results showed that sediment control was consolidated, with sediment export decreased from 7.31 ton/ha in 1975 to 4.16 ton/ha with a margin of -22.1 ton/ha to 2.27 ton/ha. Water yield decreased from 869.41 ton/ha in 1975 to 846.0 ton/ha in 1990 , plummeted to 546.0 ton/ha in 2000 and rebounded to 609.2 ton/ha in 2008, with a margin ranging from -1274.5 ton/ha to 405.5 ton/ha. Both sediment control and water yield showed a 'spatial homogenization' tendency. NPP was steady between 1990 and 2000 at 7.00 ton/ha, then jumped to 8.72 ton/ha in 2008. Correlation analyses indicated that tradeoffs existing between water yield and sediment control/NPP, and synergy between sediment control and carbon sequestration.

Climatic change and land use change play important roles in ecosystem services fluctuation. Correlation analyses showed that the decrease in precipitation hindered water yield $\left(r^{2}=0.980^{* *}\right)$ and sediment export significantly $\left(r=0.791^{* *}\right)$. The increase of temperature exerted a negative influence on water yield $\left(r=-0.350^{* *}\right)$. A spatial concordance indicated that the 'conversion from farmland to woodland/grassland' significantly influenced sediment control $\left(r^{2}=0.313^{* *}\right)$ and NPP production $\left(r^{2}=0.488^{* *}\right)$.

\section{Acknowledgments}

This research was supported by the National Basic Research Program of China (No. 2009CB421104), National Natural Science Foundation of China (No. 41230745), and External Cooperation Program of the Chinese Academy of Sciences (No. GJHZ1215). We thank Dr. Zeng Yuan and Dr. Zhu Weiwei from IRSA-CAS for helping in the calculation of the ETO of the Loess Plateau by the Penman-Monteith equation. Dr. Zhang Wenbo from Beijing Normal University provided important aid in calculating the half month rainfall erosivity. Special thanks are given to Dr. Du Xin from IRSA-CAS for assistance in applying the CASA model.

\section{References}

Arnold, J.G., Srinivasan, R., Muttiah, R.S., Williams, J.R., 1998. Large-area hydrologic modeling and assessment: Part I. Model development. Journal of the American Water Resources Association 34, 73-89.
Bennett, E.M., Peterson, G.D., Gordon, L.J., 2009. Understanding relationships among multiple ecosystem services. Ecological letters 12, 1-11.

Boumans, R., Costanza, R., May 10-11, 2007. The multi scale integrated Earth Systems model (MIMES): the dynamics, modelling and valuation of ecosystem services. Issues in Global Water System Research No. 2, "Global Assessments: Bridging Scales and Linking to Policy". Report on the Joint TIAS-GWSP Workshop. University of Maryland University College, Adelphi, USA.

Boumans, R., Costanza, R., Farley, J., Wilson, M.A., Portela, R., Rotmans, J., Villa, F., Grasso, M., 2002. Modeling the dynamics of the integrated earth system and the value of global ecosystem services using the GUMBO model. Ecological Economics 41, 529560.

Budyko, M.I., 1974. Climate and Life. Academic, San Diego, California, pp. 217-243.

Cai, Q.G., 2001. Soil erosion and management on the Loess Plateau. Journal of Geographical Sciences 11, 53-70.

Chang, R., Fu, B., Liu, G., Wang, S., Yao, X., 2012. The effects of afforestation on soil organic and inorganic carbon: a case study of the Loess Plateau of China. Catena 95, 145-152.

Chisholm, R.A., 2010. Trade-offs between ecosystem services: water and carbon in a biodiversity hotspot. Ecological Economics 69, 1973-1987.

Daily, G., 1997. Nature's Services: Societal Dependence on Natural Ecosystems. Island Press, Washington, DC, pp. 1-49.

Deng, L., Shangguan, Z.P., Li, R., 2012. Effects of the grain-for-green program on soil erosion in China. International Journal of Sediment Research 27, 120-127.

Fang, N.F., Shi, Z.H., Li, L., Jiang, C., 2011. Rainfall, runoff, and suspended sediment delivery relationships in a small agricultural watershed of the Three Gorges area, China. Geomorphology 135, 158-166.

FAO, 2002. FAOSTAT Homepage of Food and Agriculture Organization of the United Nations, Online 2008, 9/11.

Farber, S.C., Costanza, R., Wilson, M.A., 2002. Economic and ecological concepts for valuing ecosystem services. Ecological Economics 41, 375-392.

Farley, K.A., Jobbagy, E.G., Jackson, R.B., 2005. Effects of afforestation on water yield: a global synthesis with implications for policy. Global Change Biology 11, 1565-1576.

Feng, X.M., Wang, Y.F., Chen, L.D., Fu, B.J., Bai, G.S., 2010. Modeling soil erosion and its response to land-use change in hilly catchments of the Chinese Loess Plateau. Geomorphology 118, 239-248.

Fu, B., Liu, Y., Lü, Y., He, C., Zeng, Y., Wu, B., 2011. Assessing the soil erosion control service of ecosystems change in the Loess Plateau of China. Ecological Complexity 8, 284-293.

Gao, Z.L., Li, Y.H., Xu, J., Wang, Z.Z., Zhao, J., Guo, W., Zhang, X.C., Peng, K.S., 2009. Research on eco-construction and control measures of soil and water loss in the Loess Plateau. Science Technology and Industry 9, 1-12 (in Chinese with English abstract).

Jack, B.K. Kousky, C., Sims, K.R.E., 2008. Designing payments for ecosystem services: lessons from previous experience with incentive-based mechanisms. PNAS 28, 9465-9470.

Jackson, R.B., Jobbáy, E.G., Avissar, R., Roy, S.B., Barrett, D.J., Cook, C.W., Farley, K.A., Le Maitre, D.C., McCarl, B.A., Murray, B.C., 2005. Trading water for carbon with biological carbon sequestration. Science 310, 1944-1947.

Körner, C., 2000. Biosphere responses to $\mathrm{CO}_{2}$ enrichment. Ecological Applications 10, $1590-1619$.

Laflen, J.M., Lane, L.J., Foster, G.R., 1991. WEPP-a next generation of erosion prediction technology. Journal of Soil Water Conservation 46, 34-38.

Laflen, J.M., Elliot, W.J., Flanagan, D.C., Meyer, C.R., Nearing, M.A., 1997. WEPP predicting water erosion using a process-based model. Journal of Soil Water Conservation $52,96-102$

Liu, B.Y., Zhang, K.L., Xie, Y., 2002. An Empirical Soil Loss Equation//Proc. of 12th ISCO. Tsinghua Press, Beijing, pp. 143-149. 
Lü, Y., Fu, B., Feng, X., Zeng, Y., Liu, Y., Chang, R., Sun, G., Wu, B., 2012. A policy-driven large scale ecological restoration: quantifying ecosystem services changes in the Loess Plateau of China. PLoS One 7, e31782.

MA (Millennium Ecosystem Assessment), 2005. Ecosystems and Human Well- Being: Current State and Trends: Synthesis. Island Press, Washington, DC, pp. 829-838.

Matson, P.A., Lohse, K., Hall, S., 2002. The globalization of nitrogen deposition: consequences for terrestrial ecosystems. Ambio 31, 113-119.

McFarlane, D., Stone, R., Martens, S., Thomas, J., Silberstein, R., Ali, R., Hodgson, G., 2012. Climate change impacts on water yields and demands in south-western Australia. Journal of Hydrology 475, 488-498.

Monteith, J.L., Moss, C.J., 1977. Climate and the efficiency of crop production in Britain. Philosophical Transactions of the Royal Society of London (Science B) 281, 277-294.

Peng, C., Zhou, X., Zhao, S., Wang, X., Zhu, B., Piao, S., Fang, J.Y., 2009. Quantifying the response of forest carbon balance to future climate change in Northeastern China: model validation and prediction. Global and Planetary Change 66, 179-194.

Potter, C.S., Randerson, J.T., Field, C.B., Matson, P.A., Vitousek, P.M., Mooney, H.A., Klooster, S.A., 1993. Terrestrial ecosystem production: a process model based on global satellite and surface data. Global Biogeochemical Cycles 7, 811-841.

Reynolds, J.F., Stafford-Smith, D.M., 2002. Global desertification: do humans cause deserts? Dahlem Workshop Report 88. Dahlem University Press, Berlin, p. 437.

Rustad, L.E., Norby, R.J., 2002. Temperature increase: effects on terrestrial ecosystems. In: Mooney, H.A., Canadell, J.G. (Eds.), The Earth System: Biological and Ecological Dimensions of Global Environmental Change: Encyclopedia of Global Environmental Change, vol.2, pp. 575-581.

Saxton, K.E., Rawls, W.J., Romberger, J.S., Papendick, R.I., 1986. Estimating generalized soilwater characteristics from texture. Soil Science Society of America Journal 50, 1031-1036.

SCEP (Study of Critical Environmental Problems), 1970. Man's Impact on the Global Environment[M]. Springer-Verlag, Berlin.

Shang, X., Li, X.Q., 2010. Holocene vegetation characteristics of the southern Loess Plateau in the Weihe River valley in China. Review of Palaeobotany and Palynology $160,46-52$.
Su, C.H., Fu, B.J., He, C.S., Lü, Y.H., 2012. Variation of ecosystem services and human activities: a case study in the Yanhe Watershed of China. Acta Oecologica 44, 46-57.

Tallis, H.M., Kareiva, P., 2006. Shaping global environmental decisions using socioecological models. Trends in Ecology \& Evolution 21, 562-568.

Tallis, H.T., Ricketts, T., Guerry, A.D., Wood, S.A., Sharp, R., Nelson, E., Ennaanay, D., Wolny S., Olwero, N., Vigerstol, K., Pennington, D., Mendoza, G., Aukema, J., Foster, J., Forrest J., Cameron, D., Arkema, K., Lonsdorf, E., Kennedy, C., Verutes, G., Kim, C.K., Guannel, G., Papenfus, M., Toft, J., Marsik, M., Bernhardt, J., 2011. InVEST 2.2.2 User's Guide. The Natural Capital Project, Stanford.

Tang, C., Crosby, B.T., Wheaton, J.M., Piechota, T.C., 2012. Assessing streamflow sensitivity to temperature increases in the Salmon River Basin, Idaho. Global and Planetary Change 88-89, 32-44.

van Jaarsveld, A.S., Biggs, R., Scholes, R.J., Bohensky, E., Reyers, B., Lynam, T., Musvoto, C., Fabricius, C., 2005. Measuring conditions and trends in ecosystem services at multiple scales: the Southern African Millennium Ecosystem Assessment (SAfMA) experience. Philosophical Transactions of the Royal Society B-Biological Sciences 360, 425-441.

Vitousek, P.M., Mooney, H.A., Lubchenco, J., Melillo, J.M., 1997. Human domination of earth's ecosystems. Science 277, 494-499.

Wang, L., Shao, M., Wang, Q.J., Gale, W.J., 2006. Historical changes in the environment of the Chinese Loess Plateau. Environmental Science and Policy 9, 675-684.

Williams, J.R., Arnold, J.G., 1997. A system of erosion-sediment yield models. Soil Technology 11, 43-55.

Zhang, W.B., Fu, J.S., 2002. Rain erositivity estimation under different rainfall amount Recourses science 25, 35-41.

Zhang, L., Dawes, W.R., Walker, G.R., 2001. Response of mean annual evapotranspiration to vegetation changes at catchment scale. Water Resources Research 37, 701-708.

Zhang, X.P., Zhang, L., Zhao, J., Rustomji, P., Hairsine, P., 2008. Responses of stream flow to changes in climate and land use/cover in the Loess Plateau, China. Water Resource Research 44, W00A07.

Zheng, F.L., 2006. Effect of vegetation changes on soil erosion on the Loess Plateau. Pedosphere 16, 420-427. 